\title{
Proton-Coupled Electron Transfer from Tyrosine in the Interior of a de novo Protein: Mechanisms and Primary Proton Acceptor
}

\author{
Astrid Nilsen-Moe, Clorice R. Reinhardt, Starla D. Glover, Li Liang, Sharon Hammes-Schiffer,
} Leif Hammarström,* and Cecilia Tommos*

Cite This: J. Am. Chem. Soc. 2020, 142, 11550-11559

Read Online

\section{ACCESS | Llll Metrics \& More | 回 Article Recommendations | (s) Supporting Information}

ABSTRACT: Proton-coupled electron transfer (PCET) from tyrosine produces a neutral tyrosyl radical $\left(\mathrm{Y}^{\bullet}\right)$ that is vital to many catalytic redox reactions. To better understand how the protein environment influences the PCET properties of tyrosine, we have studied the radical formation behavior of $\mathrm{Y}_{32}$ in the $\alpha_{3} \mathrm{Y}$ model protein. The previously solved $\alpha_{3} \mathrm{Y}$ solution NMR structure shows that $\mathrm{Y}_{32}$ is sequestered $\sim 7.7 \pm 0.3 \AA$ below the protein surface without any primary proton acceptors nearby. Here we present transient absorption kinetic data and molecular dynamics (MD) simulations to resolve the PCET mechanism associated with $\mathrm{Y}_{32}$ oxidation. $\mathrm{Y}_{32}{ }^{\bullet}$ was generated in a bimolecular reaction with $\left[\mathrm{Ru}(\mathrm{bpy})_{3}\right]^{3+}$ formed by flash photolysis. At $\mathrm{pH}>8$, the rate constant of $\mathrm{Y}_{32}{ }^{\bullet}$ formation $\left(k_{\mathrm{PCET}}\right)$ increases by one order of magnitude per $\mathrm{pH}$ unit, corresponding to a proton-first mechanism via tyrosinate (PTET). At lower $\mathrm{pH}<7.5$, the $\mathrm{pH}$ dependence is weak and shows a

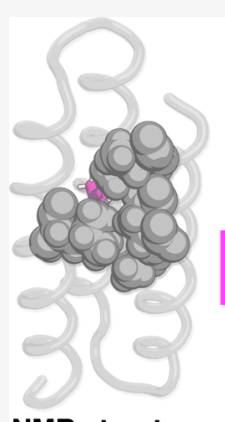

NMR structure

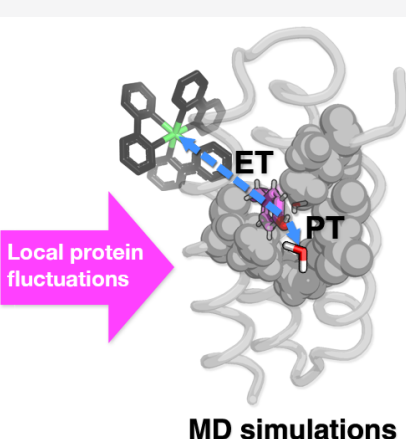
previously measured $\mathrm{KIE} \approx 2.5$, which best fits a concerted mechanism. $k_{\mathrm{PCET}}$ is independent of phosphate buffer concentration at $\mathrm{pH}$ 6.5. This provides clear evidence that phosphate buffer is not the primary proton acceptor. MD simulations show that one to two water molecules can enter the hydrophobic cavity of $\alpha_{3} \mathrm{Y}$ and hydrogen bond to $\mathrm{Y}_{32}$, as well as the possibility of hydrogen-bonding interactions between $\mathrm{Y}_{32}$ and $\mathrm{E}_{13}$, through structural fluctuations that reorient surrounding side chains. Our results illustrate how protein conformational motions can influence the redox reactivity of a tyrosine residue and how PCET mechanisms can be tuned by changing the $\mathrm{pH}$ even when the PCET occurs within the interior of a protein.

\section{INTRODUCTION}

Protein redox chemistry is at the heart of many biologically important processes such as photosynthesis, respiration, and nitrogen fixation. The large oxidoreductase class of enzymes uses a range of organic molecules and metallocofactors for catalytic and long-range electron transfer (ET) reactions. ${ }^{1-7}$ Some oxidoreductases use tyrosine (Y), tryptophan (W), cysteine, glycine, and possibly methionine as high potential one-electron redox mediators. ${ }^{7-18} \mathrm{Y}$ and $\mathrm{W}$ are of particular interest because these residues can form spatially organized chains in which high potential, one-electron oxidizing equivalents are moved over large distances. ${ }^{14-18}$ Gray and Winkler have even suggested that $\mathrm{Y} / \mathrm{W}$-based radical transfer ("hole hopping") pathways may be quite common and potentially serve as an important protective mechanism against oxidative damage. ${ }^{17,18}$ Under physiological conditions, ET from $\mathrm{Y}$ is typically coupled to proton transfer (PT) in a protoncoupled electron transfer (PCET) reaction, resulting in the formation of a neutral radical species. ${ }^{8,10,19-23}$ The thermodynamics and kinetics involved in radical formation and decay in these amino acids have direct implications for biocatalytic multistep ET/PCET processes. Thus, the study of such processes is important for (i) understanding how proteins effectively and functionally move highly oxidizing holes over large distances and (ii) directing the design of more effective biomimetic catalysts for applications such as the production of solar fuels. $^{24-27}$

Due to the complexity and size of many enzymes, it is extremely challenging to experimentally resolve the thermodynamic and kinetic behavior of a single amino-acid residue. Simplified biomimetic molecular systems that contain Y or W, but lack a protein scaffold, have proven useful in shedding light on PCET kinetics and mechanisms of radical formation in aqueous buffer. ${ }^{28-43}$ However, the thermodynamics, kinetics, and mechanisms of $\mathrm{Y}$ radical formation may not necessarily reflect the behavior that would be observed for $\mathrm{Y}$ in a protein environment. The $\alpha_{3} \mathrm{X}$ family of model proteins bridges the gap between small-molecule model systems and enzymes by providing a well-defined protein environment wherein the formation of a single amino-acid radical can be experimentally resolved. ${ }^{44}$ Thus, the $\alpha_{3} \mathrm{X}$ proteins provide a unique

Received: April 28, 2020

Published: June 1, 2020 
opportunity to study PCET quantitatively in a protein environment.

The $\alpha_{3} \mathrm{X}$ model protein system is based on a 65-residue, single-stranded three-helix bundle $\left(\alpha_{3}\right)$ with a buried, redoxactive residue $\left(\mathrm{X}_{32}\right)$ at position 32 (Figure $\left.1, \alpha_{3} \mathrm{Y}\right)$. Tyrosine

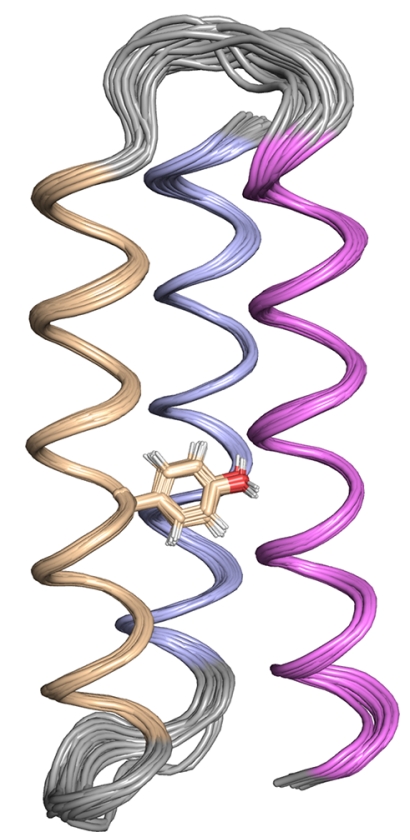

Figure 1. The $\alpha_{3} \mathrm{Y}$ protein is composed of a single chain of 65 amino acids: GSR(1)-VKALEEKVKALEEKVKA-LGGGG-RIEELKKKY (32)EELKKKIEE-LGGGGE-VKKVEEEVKKLEEEIKK-L(65), where helices 1,2 , and 3 are shown in lavender, tan, and purple, respectively. The protein ensemble structure of $\alpha_{3} \mathrm{Y}$ (PDB ID 2MI7) ${ }^{46}$ shows very little structural deviation in the 32 lowest energy states and is consistent with a globally stable and well-defined protein.

$\left(\mathrm{Y}_{32}\right),{ }^{45,46}$ tryptophan $\left(\mathrm{W}_{32}\right),{ }^{47,48}$ and a number of unnatural amino acids such as mercaptophenols, ${ }^{49,50}$ fluorotyrosines $\left(\mathrm{F}_{n} \mathrm{Y}_{32}\right.$, where $n=2$ or 3$),{ }^{51,52}$ and aminotyrosine ${ }^{53}$ have been placed in position 32. Structural studies using circular dichroism spectroscopy and solution nuclear magnetic resonance (NMR) spectroscopy have shown that the $\alpha_{3} \mathrm{X}$ proteins remain thermodynamically stable and well-folded in the $\mathrm{pH}$ range of $\sim 5-10 .^{44,45,48,49}$ A key advantage of the $\alpha_{3} \mathrm{X}$ system is that residue 32 can be reversibly oxidized and reduced. ${ }^{54}$ This property has allowed the determination of true thermodynamic reduction potentials $\left(E^{\circ \prime}\right)$ for $Y_{32}, W_{32}$, and a range of $\mathrm{Y}$ analogues incorporated at site $32.48,50-54$ Pourbaix diagrams that map $E^{\circ \prime}$ of $Y_{32}$ and $\mathrm{W}_{32}$ as a function of $\mathrm{pH}$ were obtained from protein film square-wave voltammograms collected between $\mathrm{pH} 5.5$ and $10 .^{48,52}$ The slopes of the $\mathrm{Y}_{32}$ and $\mathrm{W}_{32} E^{\circ \prime}$ vs $\mathrm{pH}$ plots were consistent with a $1 \mathrm{e}^{-} / 1 \mathrm{H}^{+}$redox process where oxidation is coupled to the release of a proton to give $\mathrm{Y}_{32}{ }^{\bullet}$ and $\mathrm{W}_{32}{ }^{\bullet}$, respectively. The $\alpha_{3} \mathrm{Y}$ and $\alpha_{3} \mathrm{~W}$ proteins were also interrogated by transient absorption (TA) spectroscopy upon oxidation by flash-quench generated $\left[\mathrm{Ru}\left(\mathrm{bpy}_{3}\right)\right]^{3+}$ (bpy $=2,2^{\prime}$-bipyridine). ${ }^{46,48}$ Transient spectra confirmed the formation of the neutral radical species $\left(\mathrm{Y}_{32}{ }^{\bullet}\right.$ and $\left.\mathrm{W}_{32}{ }^{\bullet}\right)$ when $\alpha_{3} \mathrm{Y}$ and $\alpha_{3} \mathrm{~W}$ were oxidized. From TA kinetic studies, the PCET rate constants of $\mathrm{Y}_{32}{ }^{\bullet}$ and $\mathrm{W}_{32}{ }^{\bullet}$ formation at $\mathrm{pH} 5.5$ and 8.5 were determined. In $\alpha_{3} \mathrm{Y}$, a significant kinetic isotope effect was observed at both $\mathrm{pH} 5.5$ and 8.5, suggesting that proton transfer is participating in the rate limiting step. PCET was tentatively proposed to proceed by either a concerted or stepwise proton-first (PTET) mechanism with water as the proton acceptor. ${ }^{46}$

The present work significantly extends the previous studies of tyrosine radical formation in $\alpha_{3} \mathrm{Y}$ by refining several mechanistic details concerning the formation of the $\mathrm{Y}_{32}{ }^{\bullet}$. Although it was evident from the previous study ${ }^{46}$ that PT is involved in the rate limiting step of radical formation, it was unclear if $\mathrm{Y}_{32}$ oxidation proceeded by a concerted PCET or stepwise PTET mechanism, what the primary proton acceptor was, and how the mechanism was affected by $\mathrm{pH}$. With the additional $\mathrm{pH}$ dependent radical formation kinetics data presented herein, we are able to resolve distinct mechanistic regimes of PCET in $\mathrm{Y}_{32}$. We also report kinetic data for $\mathrm{Y}_{32}{ }^{\bullet}$ formation as a function of buffer concentration. The obtained results clearly eliminate buffer, and point to $\mathrm{H}_{2} \mathrm{O}$, as the primary proton acceptor for $\mathrm{Y}_{32}$. Finally, the solution NMR structure of $\alpha_{3} \mathrm{Y}$ shows that $\mathrm{Y}_{32}$ is situated in the hydrophobic core of the protein (Figure 1). The buried $\mathrm{Y}_{32}$ residue exhibits an effective solvent accessible surface area of zero $(0.2 \pm$ $0.2 \%)$. A residue depth analysis showed that the atoms associated with $\mathrm{Y}_{32}$ and with its aromatic side chains have an average depth of $7.7 \pm 0.3$ and $8.1 \pm 0.4 \AA$, respectively. ${ }^{46}$ Based on the static $\alpha_{3} \mathrm{Y}$ structure, it was thus unclear how water gained access in order to accept the phenolic proton released from $\mathrm{Y}_{32}$ upon oxidation. To resolve this conundrum, we present molecular dynamics (MD) simulations that illustrate how structural fluctuations in the protein ensemble facilitate the proton transfer step in PCET. These combined results provide a detailed mechanistic framework that will contribute to the overall understanding of Y-based redox chemistry in enzymes.

\section{MATERIALS AND METHODS}

Sample Preparation. $\alpha_{3} \mathrm{Y}$ was expressed and purified as described previously. ${ }^{45}$ Lyophilized protein was dissolved in phosphate buffer, $\mathrm{KP}_{\mathrm{i}}\left(\mathrm{KH}_{2} \mathrm{PO}_{4}\right.$ from Sigma Life Science $\geq 99.0 \%$ purity, $\mathrm{K}_{2} \mathrm{HPO}_{4}$ from ACROS Organics $99+\%$ purity), containing 40 $\mathrm{mM} \mathrm{KCl}$ (Alfa Aesar 99.0-100.5\% purity). In experiments where kinetics was measured as a function of buffer concentration, the solutions were prepared with the following concentrations: $\left[\mathrm{KP}_{\mathrm{i}}\right]=$ 20-460 mM, $\left[\alpha_{3} \mathrm{Y}\right]=391-486 \mu \mathrm{M},\left[\left[\mathrm{Ru}(\mathrm{bpy})_{3}\right] \mathrm{Cl}_{2}\right]\left(\mathrm{bpy}=2,2^{\prime}\right.$. bipyridine $)=26-65 \mu \mathrm{M}$, and $\left[\left[\mathrm{Co}\left(\mathrm{NH}_{3}\right)_{5} \mathrm{Cl}\right] \mathrm{Cl}_{2}\right]=4 \mathrm{mM}$. In experiments where kinetics was measured as a function of $\mathrm{pH}$, solutions were prepared to the following concentrations: $\left[\mathrm{KP}_{\mathrm{i}}\right]=20-$ $40 \mathrm{mM},\left[\alpha_{3} \mathrm{Y}\right]=391-907 \mu \mathrm{M} .40 \mathrm{mM} \mathrm{KP} \mathrm{i}_{\mathrm{i}}$ was used to minimize $\mathrm{pH}$ fluctuations upon decomposition of $\left[\mathrm{Co}\left(\mathrm{NH}_{3}\right) \mathrm{Cl}\right] \mathrm{Cl}_{2}$, which generates $\mathrm{NH}_{3}$ upon quenching of $*\left[\mathrm{Ru}(\mathrm{bpy})_{3}\right] \mathrm{Cl}_{2}$ (* denotes excited species). Control experiments were carried out in the absence of $\alpha_{3} \mathrm{Y}$, where $\left[\left[\mathrm{Ru}(\mathrm{bpy})_{3}\right] \mathrm{Cl}_{2}\right]=26-65 \mu \mathrm{M}$ and $\left[\left[\mathrm{Co}\left(\mathrm{NH}_{3}\right)_{5} \mathrm{Cl}\right] \mathrm{Cl}_{2}\right]$ $=3-4 \mathrm{mM}$. Concentrations of $\alpha_{3} \mathrm{Y},\left[\mathrm{Ru}(\mathrm{bpy})_{3}\right] \mathrm{Cl}_{2}$, and $[\mathrm{Co}-$ $\left.\left(\mathrm{NH}_{3}\right)_{5} \mathrm{Cl}\right] \mathrm{Cl}_{2}$ were determined spectrophotometrically using a UV/ vis spectrometer (Agilent 8453 diode array or Cary 50) using the following extinction coefficients: $\alpha_{3} \mathrm{Y}\left(\varepsilon_{277}=1490 \mathrm{M}^{-1} \mathrm{~cm}^{-1}\right),{ }^{44}$ $\left[\mathrm{Ru}(\mathrm{bpy})_{3}\right] \mathrm{Cl}_{2}\left(\varepsilon_{452}=14600 \mathrm{M}^{-1} \mathrm{~cm}^{-1}\right),{ }^{55}$ and $\left[\mathrm{Co}\left(\mathrm{NH}_{3}\right)_{5} \mathrm{Cl}\right] \mathrm{Cl}_{2}$ $\left(\varepsilon_{532}=52 \mathrm{M}^{-1} \mathrm{~cm}^{-1}\right) .^{48}$ In all experiments, photosensitizer and quencher solutions were prepared separately and mixed under dark conditions to prevent formation of $\left[\mathrm{Ru}(\mathrm{bpy})_{3}\right]^{3+}$ and subsequent initiation of PCET prior to flash-quench experiments. The solution $\mathrm{pH}$ was adjusted with $0.1-1 \mathrm{M} \mathrm{NaOH}$ and $0.1-1 \mathrm{M} \mathrm{HCl}$ and measured using a Metrohm $654 \mathrm{pH}$ meter and a calibrated Metrohm LL Biotrode pH-electrode.

Transient Absorption Methods. The transient absorption (TA) setup has been described previously. ${ }^{46}$ In short, the sample was excited using a Nd:YAG laser (Quantel, BrilliantB) with the laser light passed through an OPO that was tuned to $460 \mathrm{~nm}$. The probe light 

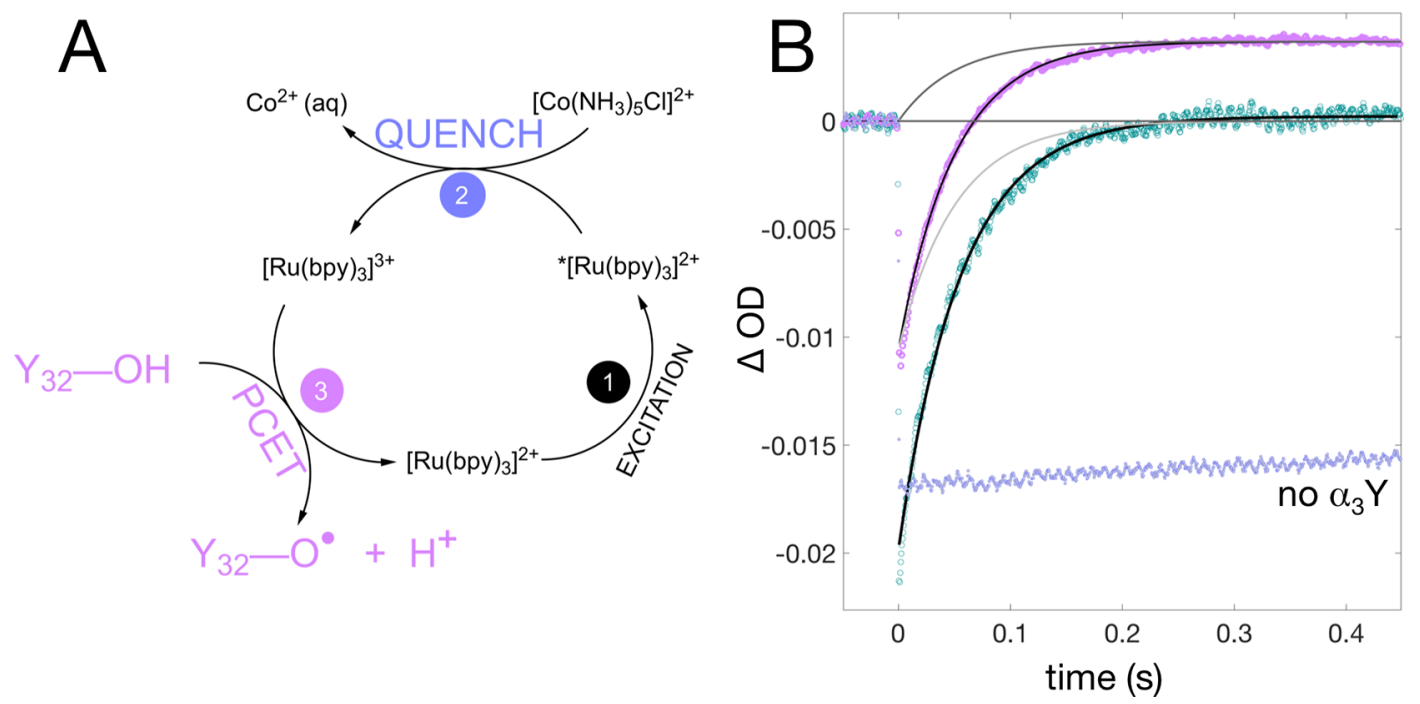

Figure 2. (A) The mechanism of $\mathrm{Y}_{32}-\mathrm{O}^{\bullet}$ generation by laser flash-quench photolysis. (B) Single $\mathrm{TA}$ traces collected at $\mathrm{pH} 6.5$ in $20 \mathrm{mM} \mathrm{KP}_{\mathrm{i}}$ buffer. Purple circles represent data recorded at $410 \mathrm{~nm}$, shown with a black line fit. The dark gray solid line shows the $\mathrm{Y}_{32}{ }^{\circ}$ component of the fit, and the light gray line shows the $\left[\mathrm{Ru}(\mathrm{bpy})_{3}\right]^{2+}$ bleach component of the fit. Green circles represent data collected at $450 \mathrm{~nm}$ with a black line fit to a single exponential decay. Blue dots represent data collected at $410 \mathrm{~nm}$ in the absence of $\alpha_{3} \mathrm{Y}$.

was directed at a right angle to the excitation light and was provided by a $150 \mathrm{~W}$ unpulsed Xe lamp that was passed through a monochromator (Applied Photophysics, pbp Spectra Kinetic Monochromator 05-109) prior to reaching the sample. The monochromator was selected for either 410 or $450 \mathrm{~nm}$ light, with 2-3 $\mathrm{mm}$ slit openings and $4.65 \mathrm{~nm} / \mathrm{mm}$ bandpass giving $\mathrm{fwhm}=9.3$ and $13.95 \mathrm{~nm}$, respectively. A second monochromator was placed after the sample and directed the probe light to the detector (PMT, Hamamatsu R928). The signal was digitized using an Agilent Technologies Infiniium digital oscilloscope $(600 \mathrm{MHz})$. TA traces were produced within the Applied Photophysics LKS software package.

Samples were contained in a $4 \times 10 \mathrm{~mm}$ cuvette where the probe light was led through the $10 \mathrm{~mm}$ path length. Oxygen was excluded from the sample during measurement by first gently purging the solution with high purity Ar for 10 min prior to measuring and then by maintaining a positive pressure of Ar during flash photolysis. TA experiments were carried out at $22-23( \pm 1)^{\circ} \mathrm{C}$.

A change of ca. $0.1-0.8 \mathrm{pH}$ units was observed for individual samples used during flash photolysis with larger changes occurring in samples having lower buffer concentrations. The $\mathrm{pH}$ of analyzed solutions was measured before and after the flash photolysis experiments. The range of $\mathrm{pH}$ values during a given flash photolysis experiment and the average $\mathrm{pH}$ were calculated from a linear interpolation of the change in $\mathrm{pH}$ as a function of the number of laser flashes supplied to the sample. The first 10 shots were not used for fitting; these traces were not reproducible due to the presence of an impurity that is rapidly consumed under oxidizing conditions (Figure S1) ${ }^{46}$ Each sample received ca. 30 laser shots, and 10-26 laser shots were averaged to obtain kinetic traces from which rate constants were extracted. The power of each laser shot was 9-12 mJ. Approximately $1-6 \mu \mathrm{M}\left[\mathrm{Ru}(\mathrm{bpy})_{3}\right]^{3+}$ was formed per shot. Data were analyzed using Matlab version $2018 \mathrm{~b}$.

Computational Methods. The solution NMR structure for $\alpha_{3} \mathrm{Y}$ served as the starting point for all simulations and was obtained from the Protein Data Bank (PDB code: 2MI7). ${ }^{46}$ As the NMR ensemble includes 32 structures, both the last conformer and the medoid (i.e., the most representative of the ensemble average, conformer 19) were selected. Independent simulations starting with each of these structures are referred to as "Traj. 1" and "Traj. 2", respectively. Each initial protein structure was solvated with explicit TIP $3 \mathrm{P}^{56}$ water in a periodic rectilinear box. The net positive charge of the protein at $\mathrm{pH} 7.0$ was neutralized with $\mathrm{Cl}^{-}$ions, followed by adding $\mathrm{Na}^{+}$and $\mathrm{Cl}^{-}$ ions to achieve a salt concentration of $\sim 150 \mathrm{mM}$. After the careful equilibration procedure described in the Supporting Information, a $1 \mu \mathrm{s} \mathrm{MD}$ trajectory in the canonical (NVT) ensemble was propagated for each initial structure. This simulation procedure was conducted with two different force fields, CHARMM $36^{57}$ and AMBER ff14SB. ${ }^{58}$ The results with these two force fields exhibit the same qualitative trends, but the CHARMM force field is known to slightly overstabilize helical structures. ${ }^{59-61}$ Therefore, the AMBER ff14SB simulations are featured in the main text, while the analogous CHARMM simulations are discussed in the Supporting Information. The root-mean-square deviations (RMSDs) for the backbone $\mathrm{C}_{\alpha}$ atoms relative to the initial structure were computed to confirm the structural stability over the $1 \mu \mathrm{s}$ trajectories (Figure S6). The root-mean-square fluctuations (RMSFs) of the $\mathrm{C}_{\alpha}$ positions per residue were also computed to identify the most flexible regions of the protein (Figure S6). A hydrogen-bonding analysis for $\mathrm{Y}_{32}$ was also conducted over all of the trajectories.

\section{RESULTS AND DISCUSSION}

Radical Formation Kinetics of $Y_{32}$. The kinetics of $Y_{32}$ oxidation was investigated between $\mathrm{pH} 5.7$ and $\mathrm{pH}$ 9.0. This $\mathrm{pH}$ range was chosen on the basis that there is no significant change in the $\alpha$-helical content, global stability, and tertiary structure of $\alpha_{3} \mathrm{Y}^{45,46}$ Figure 2A summarizes the processes that occur during laser flash photolysis under the conditions used here. $\left[\mathrm{Ru}(\mathrm{bpy})_{3}\right]^{2+}$ is excited and then oxidatively quenched by the sacrificial quencher $\left[\mathrm{Co}\left(\mathrm{NH}_{3}\right)_{5} \mathrm{Cl}\right] \mathrm{Cl}_{2}\left(k_{\mathrm{q}}=9 \times 10^{8} \mathrm{M}^{-1}\right.$ $\left.\mathrm{s}^{-1}\right)^{46}$ to form $\left[\mathrm{Ru}(\mathrm{bpy})_{3}\right]^{3+}\left(E^{\circ \prime}\left(\left[\mathrm{Ru}(\mathrm{bpy})_{3}\right]^{3+/ 2+}\right)=1260 \mathrm{mV}\right.$ vs $\mathrm{NHE}) .\left[\mathrm{Ru}(\mathrm{bpy})_{3}\right]^{3+}$ subsequently oxidizes $\mathrm{Y}_{32}$; this oxidation is coupled to proton loss, which yields $\mathrm{Y}_{32} \bullet$. The $\mathrm{Y}_{32}$ Pourbaix diagram provides an $E^{\circ \prime}(\mathrm{pH} 7.0)$ value of $986 \pm$ $3 \mathrm{mV}$ for the neutral tyrosine $\mathrm{Y}_{32}(\mathrm{O} \% \mathrm{OH})$ redox pair and a $\mathrm{pH}$ independent $E^{\circ}$ value of $749 \mathrm{mV}$ for the tyrosinate $\mathrm{Y}_{32}\left(\mathrm{O}^{\bullet} / \mathrm{O}^{-}\right.$) redox pair (see ref 52, Table S2, for a Nernst analysis of the $\alpha_{3} \mathrm{Y}$ Pourbaix diagram). ${ }^{48,52}$

Figure 2B shows TA kinetic traces obtained from an $\alpha_{3} \mathrm{Y}$ containing sample at $450 \mathrm{~nm}$ (green) and $410 \mathrm{~nm}$ (purple). The bleach at $450 \mathrm{~nm}$ is due to the depletion of $\left[\mathrm{Ru}(\mathrm{bpy})_{3}\right]^{2+}$ as a result of oxidative quenching with $\left[\mathrm{Co}\left(\mathrm{NH}_{3}\right)_{5} \mathrm{Cl}\right] \mathrm{Cl}_{2}$ (step 2 , Figure $2 \mathrm{~A})$ that produces $\left[\mathrm{Ru}(\mathrm{bpy})_{3}\right]^{3+}$. $\mathrm{Y}_{32}$ oxidation by $\left[\mathrm{Ru}(\mathrm{bpy})_{3}\right]^{3+}$ (corresponding to step 3 in Figure 2A) replenishes $\left[\mathrm{Ru}(\mathrm{bpy})_{3}\right]^{2+}$, as indicated by the recovery to the 
prepulse baseline of the TA signal at $450 \mathrm{~nm}$. Both $\left[\mathrm{Ru}(\mathrm{bpy})_{3}\right]^{2+}$ and $\mathrm{Y}_{32}{ }^{\bullet}$ absorb at $410 \mathrm{~nm}$, resulting in a bleach after the laser flash that grows to a positive signal as $\left[\mathrm{Ru}(\mathrm{bpy})_{3}\right]^{2+}$ recovers and $\mathrm{Y}_{32} \bullet$ is formed. On a slower time scale, $\mathrm{Y}_{32}{ }^{\bullet}$ dimerizes following second-order kinetics, as shown through fluorescence measurements. ${ }^{46}$ Kinetic traces collected at $410 \mathrm{~nm}$ were therefore fit to a model of pseudo-first-order formation followed by second-order decay. The fitting routine used to extract the pseudo-first-order rate constants $\left(k_{\text {obs }}\right)$ associated with radical formation is described in detail in the Supporting Information, page S5. ${ }^{62}$ Second-order PCET rate constants were calculated from $k_{\mathrm{PCET}}=k_{\mathrm{obs}} /\left[\alpha_{3} \mathrm{Y}\right]$. The yield of $\mathrm{Y}_{32}{ }^{\bullet}$ formation ranged from 0.52 to 0.75 , which is consistent with previous observations. ${ }^{46}$

The irreversible quenching produces $\mathrm{Co}^{2+}(\mathrm{aq}), \mathrm{NH}_{4}^{+}(\mathrm{aq})$, and $\mathrm{Cl}^{-}(\mathrm{aq}){ }^{63}$ The $\mathrm{Co}^{2+}$ ions formed in the quenching event (step 2, Figure 2A) react to generate Co-oxides. These complexes scatter light and exhibit broad absorption spectra in the UV and visible regions (Supporting Information of ref 46). The blue trace in Figure 2B was collected in the absence of $\alpha_{3} \mathrm{Y}$. The slow increase observed after the laser flash is due to reduction of $\left[\mathrm{Ru}(\mathrm{bpy})_{3}\right]^{3+}$ by water, $\mathrm{Co}^{2+}(\mathrm{aq})$, and Co-oxides formed under oxidizing conditions. ${ }^{46}$ We note that it is critical to minimize exposure to probe light when measuring on the ms to $s$ time scale. A monochromator was placed before the sample to filter probe light centered at 450 and $410 \mathrm{~nm}$. A control experiment in the absence of protein confirmed that the reduction of $\left[\mathrm{Ru}(\mathrm{bpy})_{3}\right]^{3+}$ by side reactions is significantly slower than the observed rate constants in the presence of $\alpha_{3} \mathrm{Y}$. Control experiments using $\alpha_{3} \mathrm{X}$ with redox inactive phenylalanine at position 32 have previously shown similar slow kinetics. ${ }^{46}$ As PCET rates associated with $\mathrm{Y}_{32}{ }^{\bullet}$ formation are significantly faster than Co-oxide formation, kinetic traces obtained in the presence of the protein can be attributed solely to $\mathrm{Y}_{32}{ }^{\bullet}$ formation (Figure S2). Additional control experiments without $\alpha_{3} \mathrm{Y}$ also confirmed that Co-oxide formation does not increase with buffer concentration (Figure S3).

PCET Rate Constants as a Function of $\mathrm{pH}$ and Buffer Concentration. Bimolecular rate constants for oxidation of $\mathrm{Y}_{32}$ by $\left[\mathrm{Ru}(\mathrm{bpy})_{3}\right]^{3+}$ were determined at $\mathrm{pH}$ values from 5.7 to 9.0 using kinetics from ns laser flash photolysis, Figure 3. The data shows a steep $\mathrm{pH}$ dependence at high $\mathrm{pH}$ where a 10 -fold increase in rate constant per $\mathrm{pH}$ unit is observed. The $\mathrm{pH}$ dependence is weaker below ca. $\mathrm{pH}$ 7.5. The phenomena giving rise to the observed trend in PCET rate constants $\left(k_{\mathrm{PCET}}\right)$ are discussed below.

The fractions of tyrosine and tyrosinate $\left(f_{\mathrm{YOH}}\right.$ and $f_{\mathrm{YO}^{-}}$, respectively) change with $\mathrm{pH}$, and $k_{\mathrm{PCET}}$ can be expressed as a sum of these fractions multiplied by their respective oxidation rate constants $\left(k_{\mathrm{YOH}}\right.$ and $\left.k_{\mathrm{YO}^{-}}\right)$:

$$
k_{\mathrm{PCET}}=k_{\mathrm{YOH}} f_{\mathrm{YOH}}+k_{\mathrm{YO}^{-}} f_{\mathrm{YO}^{-}}
$$

$f_{\mathrm{YOH}}$ is close to unity $(>0.99)$ throughout the $\mathrm{pH}$ 5.7-9.0 range studied and can therefore be treated as independent of $\mathrm{pH}$. $f_{\mathrm{YO}^{-}}$can be approximated as $10^{\mathrm{pH}-\mathrm{pKa}}$ from the Henderson-Hasselbalch equation, thus obtaining the following relation:

$$
k_{\mathrm{PCET}}=k_{\mathrm{YOH}}+k_{\mathrm{YO}^{-}} \times 10^{\mathrm{pH}-\mathrm{p} K_{\mathrm{a}}}
$$

$k_{\text {PCET }}$ as a function of $\mathrm{pH}$ was fit to eq 2 , using an apparent $\mathrm{p} K_{\mathrm{a}}$ of 11.3 for $\mathrm{Y}_{32}{ }^{44}$ shown in purple (solid line, Figure 3). The fit

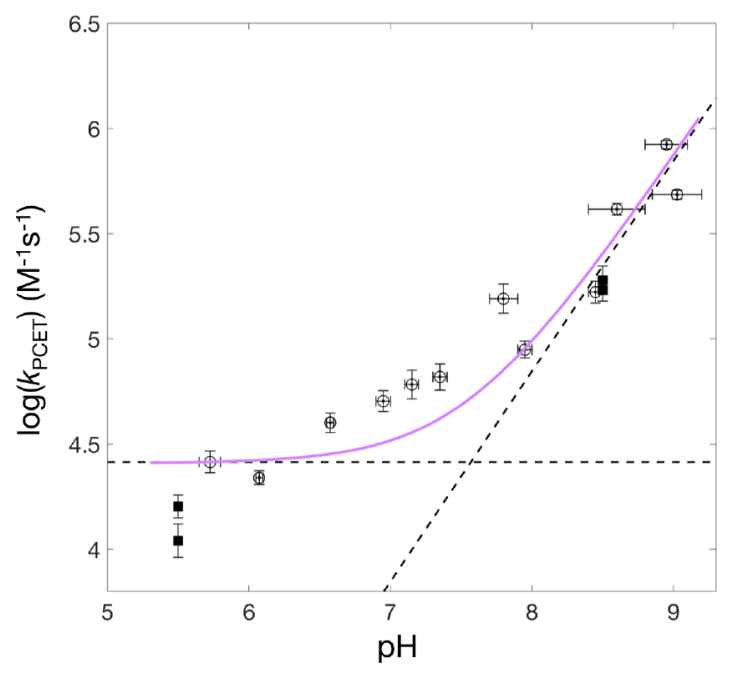

Figure 3. Rate constants of PCET versus $\mathrm{pH}$ for $\alpha_{3} \mathrm{Y}$ (black circles). Solid black squares represent data from ref 46 . The purple solid line is a fit to eq 2, where $k_{\mathrm{YOH}}=2.6 \times 10^{4} \mathrm{M}^{-1} \mathrm{~s}^{-1}$ and $k_{\mathrm{YO}^{-}}=1.4 \times 10^{8}$ $\mathrm{M}^{-1} \mathrm{~s}^{-1}\left(R^{2}=0.87\right)$. The dashed lines show the $\mathrm{pH}$ independent and $\mathrm{pH}$ dependent terms of the fit. Vertical error bars correspond to \pm one standard deviation. Horizontal error bars correspond to the change in $\mathrm{pH}$ over the course of the flash photolysis experiment.

resulted in $k_{\mathrm{YOH}}=2.6 \times 10^{4} \mathrm{M}^{-1} \mathrm{~s}^{-1}$ and $k_{\mathrm{YO}^{-}}=1.4 \times 10^{8} \mathrm{M}^{-1}$ $\mathrm{s}^{-1}$.

The equilibrium concentration of deprotonated $\mathrm{Y}_{32}$ at $\mathrm{pH}$ 8-9 is similar to, or even lower than, that of $\left[\mathrm{Ru}(\mathrm{bpy})_{3}\right]^{3+}$ created in one flash (roughly $0.25 \mu \mathrm{M}$ compared to $1-6 \mu \mathrm{M}$, respectively, for each species at $\mathrm{pH} 8$ ). Still TA kinetics from $\mathrm{pH}$ 8-9 showed single exponential behavior (pseudo-firstorder conditions), suggesting that $f_{\mathrm{YO}^{-}}$is constant during the experiment. This means that the equilibrium between protonated and deprotonated $\mathrm{Y}_{32}$ is fast on the time scale of $\mathrm{Y}_{32}$ oxidation in these experiments (ca. $0.5 \mathrm{~s}$ ), and the PCET mechanism dominating at $\mathrm{pH}>8$ is a rapid pre-equilibrium PT with subsequent ET. Rate-limiting PT, or concerted PCET, to $\mathrm{OH}^{-}$or buffer species can be excluded (see the Supporting Information, page S8). The observed increase in $k_{\mathrm{PCET}}$ at $\mathrm{pH}>$ 8 is due to the increasing equilibrium fraction of tyrosinate $\left(f_{\mathrm{YO}^{-}}\right)$. From the rate constants determined for protonated and deprotonated $\mathrm{Y}_{32}$, we note that the difference in reactivity between the tyrosinate/tyrosine forms of $\alpha_{3} \mathrm{Y}$ and freely solvated phenolate/phenol in aqueous solution is small, within experimental accuracy. With $\left[\mathrm{Ru}(\mathrm{bpy})_{3}\right]^{3+}$ as oxidant in both cases, $k_{\mathrm{YO}}-/ k_{\mathrm{YOH}} \approx 5000$ (from eqs 1 and 2 ) for $\mathrm{Y}_{32}$, and the corresponding ratio for phenolate/phenol is $k_{\mathrm{PhO}}-/ k_{\mathrm{PhOH}} \approx$ $9000 .^{64}$ Even if both rate constants are about 10 times smaller for the protein, the ratios are similar and of the same order of magnitude. ET from $\mathrm{Y}_{32}$ is expected to be slower than ET from phenol due to a greater electron donor-acceptor distance and a lower diffusion rate constant. The near identical $k_{\mathrm{YO}}-/ k_{\mathrm{YOH}}$ and $k_{\mathrm{PhO}} / k_{\mathrm{PhOH}}$ ratios suggest that there is no additional kinetic obstacle for proton transfer from $\mathrm{Y}_{32}$, despite its average location of $7.7 \pm 0.3 \AA$ inside the protein.

At $\mathrm{pH}<7.5$, the PCET oxidation of protonated $\mathrm{Y}_{32}\left(k_{\mathrm{YOH}}\right)$ is the dominant contribution to $k_{\mathrm{PCET}}$. A significant kinetic isotope effect $(\mathrm{KIE}=2.5 \pm 0.5)$ was observed for PCET rate constants at $\mathrm{pH}$ 5.5, from which an ETPT mechanism can be excluded. ${ }^{46}$ With the extended $\mathrm{pH}$ dependent data (Figure 3), PTET can also be excluded. The observed $\mathrm{pH}$ dependence of $k_{\mathrm{YOH}}$ is much weaker than the factor of 10 per $\mathrm{pH}$ unit 
predicted for a PTET mechanism with $\mathrm{OH}^{-}, \mathrm{HPO}_{4}{ }^{2-}$, or $\mathrm{PO}_{4}{ }^{3-}$ as proton acceptor. Thus, we can now establish that the oxidation of the neutral $\mathrm{Y}_{32}$ in $\alpha_{3} \mathrm{Y}$ by external $\left[\mathrm{Ru}(\mathrm{bpy})_{3}\right]^{3+}$ proceeds as a concerted PCET mechanism. Even a concerted PCET with $\mathrm{OH}^{-}, \mathrm{HPO}_{4}{ }^{2-}$, or $\mathrm{PO}_{4}{ }^{3-}$ as primary proton acceptor would have given a 10 -fold increase in rate constant per $\mathrm{pH}$ unit, following the first-order dependence on the proton acceptor concentration. This prediction seems to exclude those species.

To confirm that no buffer species were directly involved in the reaction, $k_{\mathrm{PCET}}$ for $\mathrm{Y}_{32}$ was measured in $\mathrm{pH} 6.5$ phosphate buffer with concentration ranging from 20 to $460 \mathrm{mM}$ (Figure 4). If phosphate acts as the primary proton acceptor at $\mathrm{pH}<$

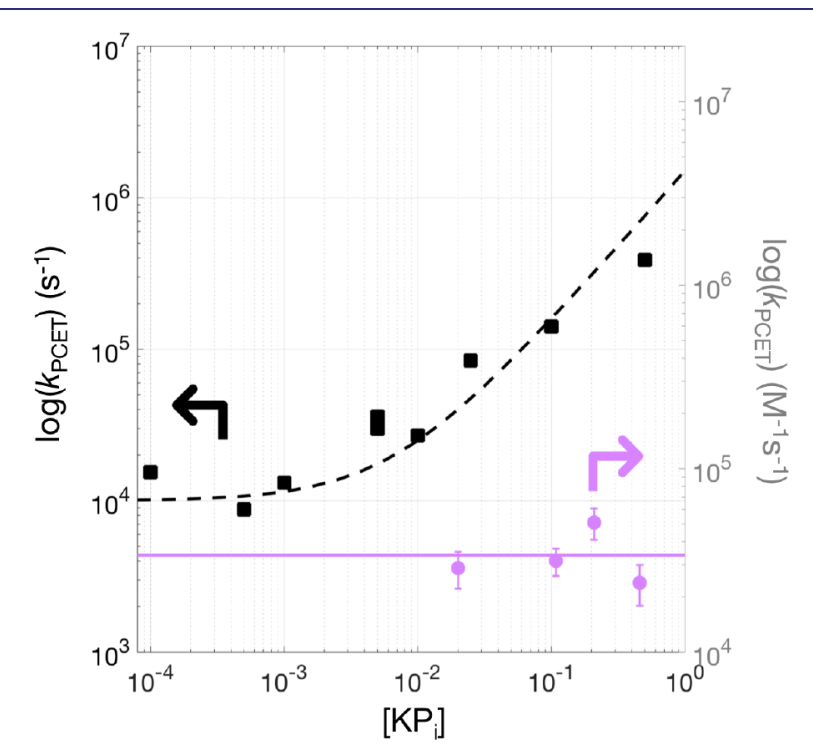

Figure 4. PCET rate constants measured in phosphate buffer. Error bars are shown when the error is larger than the marker. The left $y$ axis represents first-order rate constants for $\mathrm{Ru}-\mathrm{Y}$, and the right $y$ axis, second-order rate constants for $\alpha_{3} \mathrm{Y}$. Black squares show data collected for $\mathrm{Ru}-\mathrm{Y}$ in $\mathrm{pH} 7$ phosphate buffer with a fit to the data using $k_{\mathrm{obs}}=k_{\mathrm{b}}+f_{\mathrm{b}}[$ buffer $] k_{\mathrm{b}}{ }^{32}$ (dashed black line). Purple circles show data for $\alpha_{3} \mathrm{Y}$ collected in $\mathrm{pH} 6.5$ phosphate buffer with a linear, constant value fit to the data (solid purple line).

$7.5, k_{\mathrm{PCET}}$ is expected to increase with the phosphate concentration in the buffer. At $\mathrm{pH} 6.5$, approximately $17 \%$ of the buffer exists in the $\mathrm{HPO}_{4}{ }^{2-}$ form $\left(\mathrm{H}_{2} \mathrm{PO}_{4}{ }^{-} \mathrm{pK} K_{\mathrm{a}}=7.2\right)$, which means that $\left[\mathrm{HPO}_{4}{ }^{2-}\right]$ was varied from 3.3 to $76 \mathrm{mM}$ (20-fold increase). pH 6.5 was chosen for two reasons. First, the Co-oxide formation is slow enough that concentrations of $\alpha_{3} \mathrm{Y}$ could be kept to $<500 \mu \mathrm{M}$ without kinetic interference from the Co-oxide reactions. Second, at $\mathrm{pH} 6.5$, only $0.002 \%$ of $\mathrm{Y}_{32}$ is in its deprotonated form, indicating that $k_{\mathrm{YOH}} \gg k_{\mathrm{YO}^{-}}$ $\times 10^{\mathrm{pH}-\mathrm{p} K_{\mathrm{a}}}$, thus ensuring that PCET from protonated $\mathrm{Y}_{32}$ dominates. The PCET rate constants for $\mathrm{Y}_{32}$ as a function of buffer concentration are compared to PCET rate constants previously reported for a covalently linked ruthenium photosensitizer-tyrosine model complex, ${ }^{32} \mathrm{Ru}-\mathrm{Y}$ (chemical structure in Figure S5). PCET rate constants for $\mathrm{Ru}-\mathrm{Y}$ are given in Figure 4 (black squares); PCET proceeds with an intramolecular ET, and therefore, the rate constants are of first order. $\mathrm{Ru}-\mathrm{Y}$ exhibits a buffer independent region at low phosphate concentrations $(<1 \mathrm{mM})$ and a region that is first order in phosphate concentrations above $10 \mathrm{mM}$, indicating that phosphate $\left(\mathrm{HPO}_{4}{ }^{2-}\right)$ acts as the primary proton acceptor only at high enough concentrations of buffer and that water is the primary proton acceptor at low buffer concentrations. ${ }^{32}$ In contrast, $k_{\mathrm{PCET}}$ in $\mathrm{Y}_{32}$ is clearly independent of $\left[\mathrm{KP}_{\mathrm{i}}\right]$ even at higher phosphate concentrations (Figure 4, purple circles), showing that phosphate is not the primary proton acceptor in the oxidation of $\mathrm{Y}_{32}$. Thus, the absence of viable proton acceptors nearby $\mathrm{Y}_{32}$ in $\alpha_{3} \mathrm{Y}$ and the exclusion of $\mathrm{OH}^{-}$and buffer species strongly suggest that water $\left(\mathrm{H}_{2} \mathrm{O}\right)$ is the primary proton acceptor in the concerted PCET reaction of $\alpha_{3} \mathrm{Y}$ $\left(k_{\mathrm{YOH}}\right)$.

From a thermodynamic perspective, $\mathrm{HPO}_{4}{ }^{2-}$ is a much better proton acceptor than water $\left(\mathrm{H}_{3} \mathrm{O}^{+}, \mathrm{p} K_{\mathrm{a}}=0\right.$ per definition). Despite the thermodynamic advantage of PT to phosphate, the strongly distance dependent PT step requires that the proton acceptor penetrates the protein to get near the $\mathrm{Y}_{32} \mathrm{OH}$ group. The finding that buffer does not act as a proton acceptor suggests that the $\mathrm{HPO}_{4}{ }^{2-}$ or $\mathrm{PO}_{4}{ }^{3-}$ do not come in close enough contact with $\mathrm{Y}_{32}$. This could be due to their larger size compared to water, as well as their negative charge.

The kinetic data are, however, not completely independent of $\mathrm{pH}$ below 7.5 where it deviates from the fit. Having excluded buffer dependence, another possible reason for the $\mathrm{pH}$ dependence of $k_{\mathrm{YOH}}$ is that the global surface charge of the protein changes with $\mathrm{pH} . \alpha_{3} \mathrm{Y}$ and $\alpha_{3} \mathrm{~W}$ have an isoelectric point of $\sim 8$, as shown by isoelectric gel electrophoresis. ${ }^{48}$ As the $\mathrm{pH}$ increases, amino acid residues become negatively charged, until the isoelectric point is reached and the protein has an overall neutral charge. For comparison, the oxidation of $\alpha_{3} \mathrm{~W}$ was assigned to an ET-limited ETPT mechanism at $\mathrm{pH}$ 5.5 and $8.5^{48}$ where PCET rate constants should be $\mathrm{pH}$ independent. PCET rate constants for $\alpha_{3} \mathrm{~W}$ increased by a factor of 1.3 between $\mathrm{pH} 5.5$ and 8.5, corresponding to a factor of 1.1 increase per $\mathrm{pH}$ unit. ${ }^{48} \alpha_{3} \mathrm{Y}$ and $\alpha_{3} \mathrm{~W}$ have the same protein sequence with the exception of site 32 and similar three-helix bundle solution structures. ${ }^{46,48}$ The protein surface charge interactions with $\left[\mathrm{Ru}(\mathrm{bpy})_{3}\right]^{3+}$ should therefore be nearly identical for $\alpha_{3} \mathrm{Y}$ and $\alpha_{3} \mathrm{~W}$. Inclusion of a 1.1 factor increase per $\mathrm{pH}$ unit to the otherwise $\mathrm{pH}$ independent term $k_{\mathrm{YOH}}$ only marginally improves the fit of $\mathrm{pH}$ dependent PCET rate constants for $\alpha_{3} \mathrm{Y}$ (Figure S4). Thus, the change in electrostatic interaction between $\alpha_{3} \mathrm{Y}$ and $\left[\mathrm{Ru}(\mathrm{bpy})_{3}\right]^{3+}$ does not explain the weak $\mathrm{pH}$ dependence observed at $\mathrm{pH}<7.5$. We note that a similarly weak dependence of the concerted PCET reaction for aqueous $\mathrm{Ru}-\mathrm{Y}$ has been reported, ${ }^{41}$ but a theoretical explanation is still lacking.

The weak $\mathrm{pH}$ dependence for $k_{\mathrm{PCET}}$ at low $\mathrm{pH}$, where $k_{\mathrm{YOH}}$ dominates, could be due to protein conformational motions. Increasing the $\mathrm{pH}$ may favor conformational motions that permit water access to $Y_{32}$ to a greater extent. Although studying the dependence of protein conformational motions on $\mathrm{pH}$ is challenging, $\mathrm{MD}$ simulations can provide more general insights into equilibrium conformational motions of the protein and surrounding water. Herein, MD simulations were performed to investigate the possible influence of protein motions on the PCET reactivity of $Y_{32}$, particularly focusing on water accessibility.

Protein Molecular Dynamics Simulations. The solvent accessibility of $\mathrm{Y}_{32}$ in $\alpha_{3} \mathrm{Y}$ was explored through $1 \mu \mathrm{s} \mathrm{MD}$ simulations. Although the $\alpha_{3}$ protein scaffold was designed to sequester $\mathrm{Y}_{32}{ }^{44}$ these simulations show that $\mathrm{H}_{2} \mathrm{O}$ can reach the $\mathrm{Y}_{32}$ site through structural fluctuations in nearby side chains. This phenomenon was observed for two different starting structures and two different force fields, suggesting that $\mathrm{Y}_{32}$ is 

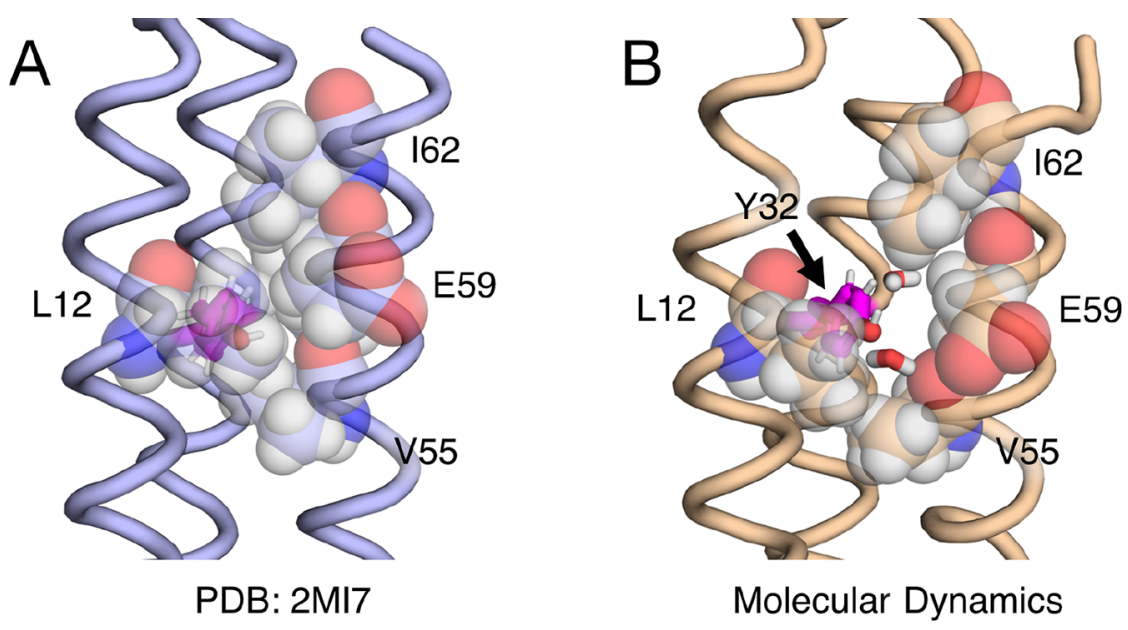

Figure 5. Illustration of side chain motions observed in an MD trajectory propagated with the AMBER ffl4SB force field. (A) The starting structure from the $\alpha_{3} \mathrm{Y}$ solution NMR structure. ${ }^{46}$ (B) A configuration from the MD trajectory in which two water molecules transiently reside within hydrogen-bonding distance to $\mathrm{Y}_{32}$. The backbone is depicted as tubes, and the residues occluding water access in panel A or bordering the water channel in panel $\mathrm{B}$ are depicted as spheres.
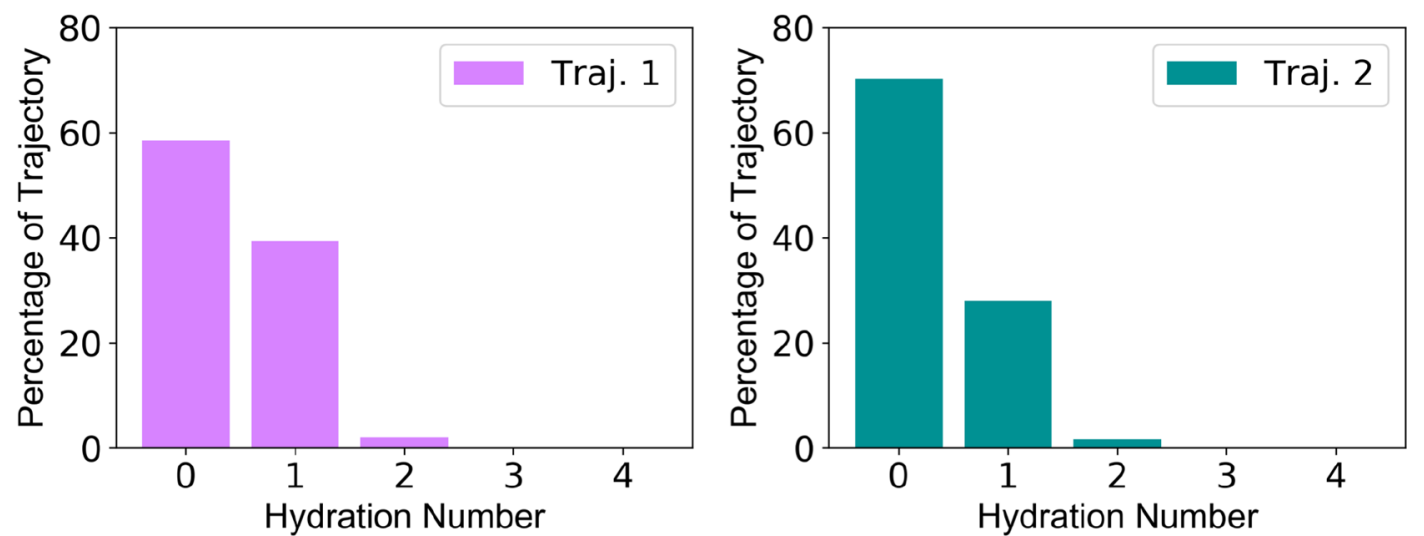

Figure 6. Histograms of hydration number for MD trajectories propagated with the AMBER ff14SB force field.

able to briefly hydrogen bond to water. In the solution NMR structure, surrounding nonpolar side chains occlude water access to $\mathrm{Y}_{32}$ (Figure 5A). Using the AMBER ff14SB force field, $\mathrm{MD}$ simulations revealed protein conformations in which the side chain of $\mathrm{L}_{12}$ had rotated, forming a small void that transiently allowed water access and hydrogen-bonding interactions with $\mathrm{Y}_{32}$ (Figure 5B). Similar conformations were observed with the CHARMM36 force field and are shown in Figure S7. An additional conformation sampled with the AMBER ff14SB force field, in which $\mathrm{Y}_{32}$ has rotated to face outward, and the hydrophobic side chains have repacked the core, is shown in Figure S8. The prevalence of these transient side chain fluctuations and the associated hydrogen bond between $Y_{32}$ and water is force field dependent, and thus, the probability of sampling these conformations cannot be established definitively from these simulations.

The water occupancy around $\mathrm{Y}_{32}$ was analyzed by computing the hydration number around $\mathrm{Y}_{32}$. Here the hydration number is defined as the number of water molecules with the oxygen atom within $3.0 \AA$ of the $\mathrm{Y}_{32}$ hydroxyl oxygen. The average hydration number for $\mathrm{Y}_{32}$ was computed to be 0.49 and 0.35 for Traj. 1 and Traj. 2, respectively. These fractional values of the average hydration number indicate that, in a majority of the sampled protein configurations, $\mathrm{Y}_{32}$ is hydrogen bonded to either no water molecules or one water molecule (Figure 6). Two water molecules were within $3.0 \AA$ of the $\mathrm{Y}_{32}$ hydroxyl group for a small number of configurations (Figure 6). The hydrogen-bonding interaction of the $\mathrm{Y}_{32}$ hydroxyl group with water was analyzed by defining a hydrogen bond according to the criteria of a heavy atom distance less than or equal to $3.0 \AA$ and a donor-hydrogenacceptor angle greater than or equal to $135^{\circ}$. The percentage of a given trajectory with $\mathrm{Y}_{32}$ forming at least one hydrogen bond to a water molecule was computed to be 38.2 and $27.7 \%$ for Traj. 1 and Traj. 2, respectively. The differences between these percentages and the average hydration numbers arise from the configurations with $Y_{32}$ simultaneously hydrogen bonded to two water molecules. $Y_{32}$ is also observed to hydrogen bond to the backbone carbonyl oxygen atoms of $\mathrm{L}_{12}$ and $\mathrm{L}_{58}$, the carbonyl of $\mathrm{V}_{9}$, or the carboxylate of the nearby $\mathrm{E}_{13}$ (Table 1 ). For a majority of the MD trajectories, these hydrogen bonds within the protein form when $\mathrm{Y}_{32}$ is not hydrogen bonded to water, although simultaneous hydrogen-bonding interactions are possible (Figure S8). The analogous breakdown of hydrogen bonds for the trajectories propagated with the CHARMM36 force field is given in Table S3.

For the hydrogen bonds between $\mathrm{Y}_{32}$ and water or $\mathrm{E}_{13}$, the donor-acceptor distance fluctuates and samples shorter distances that would enable proton transfer. Specifically, the $\mathrm{MD}$ trajectories propagated with the AMBER ff14SB force 
Table 1. Hydrogen-Bonding Interactions Involving $Y_{32}$ for MD Trajectories of $\alpha_{3} Y$ Propagated with the AMBER ff14SB Force Field

\begin{tabular}{llcccc} 
& $\mathrm{V}_{9}: \mathrm{O}$ & $\mathrm{E}_{13}: \mathrm{O} \varepsilon_{1}, \varepsilon_{2}$ & $\mathrm{~L}_{58}: \mathrm{O}$ & $\mathrm{L}_{12}: \mathrm{O}$ & WAT:O \\
\hline Traj. 1 & $54.1 \%$ & $24.0 \%$ & $5.12 \%$ & & $38.2 \%$ \\
Traj. 2 & $39.38 \%$ & $21.56 \%$ & $3.98 \%$ & $3.32 \%$ & $27.7 \%$
\end{tabular}

${ }^{a}$ The numbers reported reflect the sum of the hydrogen-bonding interactions with $\mathrm{Y}_{32}$ acting as a H-bond acceptor or donor and can include contributions from multiple water molecules.

field sampled hydrogen bond donor-acceptor distances in the range $2.5-2.75 \AA$ for around $10 \%$ of the trajectory, indicating that proton transfer could occur in either case (Figure 7). However, the distributions of distances sampled during the $\mathrm{MD}$ trajectories differ between water and $\mathrm{E}_{13}$, with water sampling shorter distances more frequently, as reflected by the percentages in Table 1 and the distributions in Figures 7 and S9.

The hydrogen bonding between $\mathrm{Y}_{32}$ and water is significantly less prevalent for the trajectories propagated with the CHARMM36 force field (Table S3 and Figure S10), most likely due to overstabilization of the compact $\alpha$-helix. $\mathrm{Y}_{32}$ was observed to be significantly more flexible for the trajectories propagated with the AMBER force field compared to those propagated with the CHARMM force field, as indicated by the $\mathrm{Y}_{32}$ RMSFs given in Table S4. Because of this diminished flexibility, when $Y_{32}$ is not hydrogen bonded to water, it hydrogen bonds only to the backbone carbonyl oxygen atoms of $\mathrm{L}_{12}$ and $\mathrm{L}_{58}$ for the trajectories propagated with the CHARMM36 force field (Table S3). Despite the quantitative differences observed for the two different force fields, all of the trajectories exhibited the same qualitative trends. In particular, all of the trajectories illustrate that $\mathrm{Y}_{32}$ can become accessible to water through rotations and fluctuations of the surrounding nonpolar side chains.

The interaction between the $-\mathrm{OH}$ group of $\mathrm{Y}_{32}$ and the $\mathrm{E}_{13}$ carboxylate group observed with the AMBER ff14SB force field could result in proton transfer to $\mathrm{E}_{13}$, which is deprotonated in the MD simulations. $\alpha_{3} \mathrm{Y}$ may not be structurally well-defined at $\mathrm{pH}$ values below the $\mathrm{p} K_{\mathrm{a}}$ of $\mathrm{E}_{13}(\sim 4.3)$ which hinders us from determining rate constants in a $\mathrm{pH}$ range where $\mathrm{E}_{13}$ is protonated to rule out this residue as a potential proton acceptor. The $\mathrm{E}_{13}$ interaction has not been sampled with the
CHARMM36 force field, which may be due to its overstabilization of helical structures. At present, it is not possible to determine which force field represents the experimental conditions more accurately. Despite these differences between the two force fields, the formation of the water cavity is observed with both of them.

General Discussion. Tyrosine becomes strongly acidic upon oxidation, resulting in a deprotonated neutral radical. ${ }^{19}$ The deprotonation mechanism can vary depending on the surroundings. To activate buried $\mathrm{Y}$ residues for redox chemistry, enzymes have evolved the placement of an internal proton acceptor within hydrogen-bonding distance. Such an acceptor can act to shuttle the proton back and forth upon redox cycling of the tyrosine (e.g., the $\mathrm{Y}_{\mathrm{Z}}$-histidine and $\mathrm{Y}_{\mathrm{D}}-$ histidine pairs in PSII). ${ }^{11,65}$ In other cases, proton channels with several acid/base groups connect the PCET reaction with proton transport to or from the bulk solvent. For Y residues close to the protein surface, Brønsted bases in solution, such as water itself, may act as the primary proton acceptor. Water assisted PCET has recently been suggested to facilitate radical transfer between the $\alpha$ and $\beta$ subunits in E. coli ribonucleotide reductase $(\mathrm{RNR}){ }^{66}$ In $\mathrm{RNR}$, radical transfer occurs reversibly over $>32 \AA^{67}$ between a network of Ys where each radical transfer step is likely a concerted PCET mechanism. The radical transfer chain crosses over the $\alpha$ and $\beta$ subunits of the protein where the distance between the donating and accepting tyrosines is $>5 \AA$. Water is found between the subunits and is believed to aid the radical transfer. There is still much to learn about single water molecules or small water clusters acting as proton acceptors in PCET reactions, and RNR is not the only case reported thus far. ${ }^{68}$

The $\alpha_{3} \mathrm{Y}$ kinetic data and MD simulations presented in this report have shed light on the radical formation process. $\mathrm{Y}_{32}$ is occluded from solvent by nonpolar side chains and residues on average $7.7 \pm 0.3 \AA$ below the protein surface. The $\mathrm{Y}_{32}$ pocket is composed of hydrophobic residues that cannot act as proton acceptors. Our MD simulations show that protein fluctuations can transiently form a cavity in the protein that allows water to approach within hydrogen-bonding distance of the $\mathrm{Y}_{32}$ side chain. Within the time scale of our simulations, $\mathrm{Y}_{32}$ interacts with one water molecule at a time, although for a small number of configurations, two water molecules were within $3 \AA$ of the $\mathrm{Y}_{32}$ oxygen. It is likely that such water molecules serve as the primary proton acceptor. In a later step, the proton would then
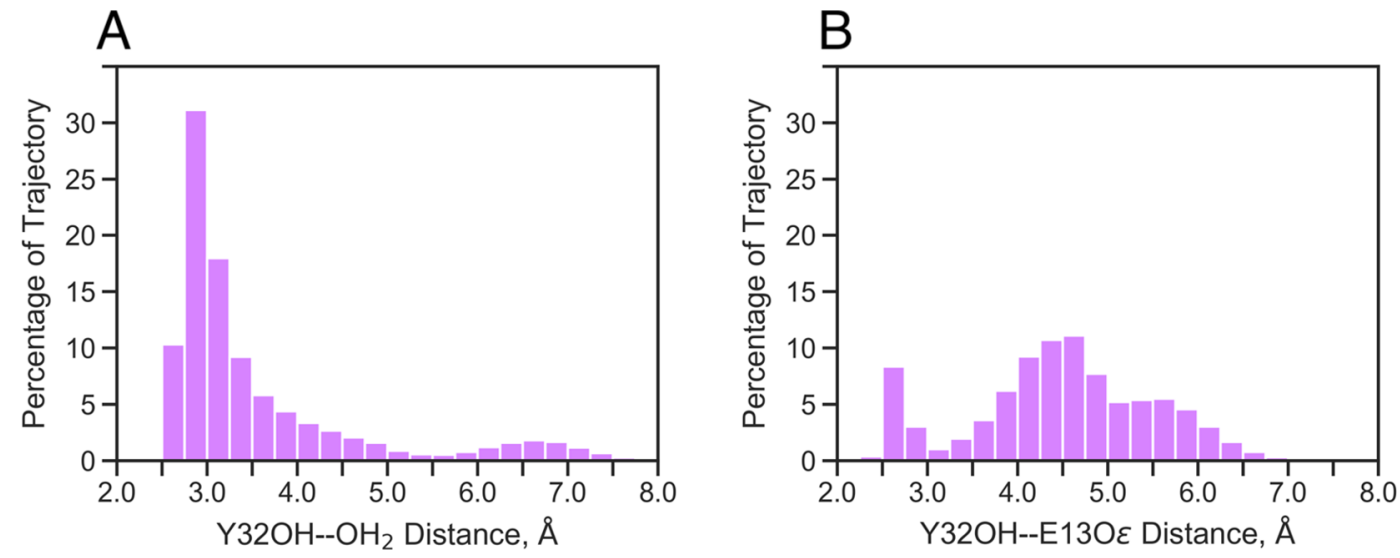

Figure 7. Histograms of $\mathrm{O}-\mathrm{O}$ distances between the hydroxyl oxygen of $\mathrm{Y}_{32}$ and the closest water molecule (A) and the hydroxyl oxygen of $\mathrm{Y}_{32}$ and the closest carboxylate oxygen of $\mathrm{E}_{13}$ (B) for the first MD trajectory (Traj. 1) propagated with the AMBER ff14SB force field. 
be transferred further to bulk water. The small size of the cavity is likely the reason that phosphate buffer $\left(\mathrm{HPO}_{4}{ }^{2-} / \mathrm{PO}_{4}{ }^{3-}\right)$ cannot compete as the primary proton acceptor. It should be noted that one of the force fields used in the MD simulations also suggests the possibility of $\mathrm{E}_{13}$ as a potential proton acceptor, which will be further examined in future studies.

\section{CONCLUSIONS}

The rate constants of $\mathrm{Y}_{32}{ }^{\bullet}$ formation have been determined as a function of $\mathrm{pH}$ and buffer concentration. The PCET mechanism is most likely a combination of PTET via $\mathrm{Y}_{32}{ }^{-}$ (dominating at high $\mathrm{pH}$ ) and concerted PCET (dominating at low $\mathrm{pH}$ ) with water as the primary proton acceptor across the entire $\mathrm{pH}$ range studied. Our results show how the rate constants and PCET mechanism of a buried Y residue can be influenced by the protein environment in combination with the solution $\mathrm{pH}$. The primary proton acceptor is either water or a glutamate $\left(E_{13}\right)$ located $\geq 6.7 \AA$ from $Y_{32}$ in the NMR structure. Molecular dynamics simulations show that water access to $Y_{32}$ is facilitated by structural fluctuations of nearby side chains, forming a transient cavity. It should be noted that, while the cavity allowing for water access was seen in all trajectories using two different force fields, the $\mathrm{E}_{13}$ interaction was only seen with one force field (AMBER ff14SB). Local protein fluctuations allow for approach of the primary proton acceptor to form a transient hydrogen bond with $\mathrm{Y}_{32}$. This enables rapid oxidation of $Y_{32}$ in spite of its location $7.7 \pm 0.3$ Å from the protein surface.

The $\alpha_{3} \mathrm{X}$ family of proteins strikes a balance between small model systems and enzymes, making it ideal for mechanistic and quantitative PCET studies. The $\alpha_{3} \mathrm{X}$ model proteins are structurally well-defined and exhibit the characteristic cooperative behavior of natural proteins. At the same time, the $\alpha_{3} \mathrm{X}$ proteins provide unambiguous kinetic and thermodynamic details of PCET that are highly challenging and often not possible to obtain from the natural enzyme systems. Our results clearly illustrate the importance of protein conformational motions in mediating PCET. Future PCET studies on the $\alpha_{3} \mathrm{X}$ model system will address how radical formation is affected by modulating the microenvironment of the radical site including solvent exposure and hydrogen-bonding interactions. Such studies can provide key insights into PCET amino acid radical behavior in natural systems.

\section{ASSOCIATED CONTENT}

\section{SI Supporting Information}

The Supporting Information is available free of charge at https://pubs.acs.org/doi/10.1021/jacs.0c04655.

Additional TA kinetics, data fitting routines, tabulated rate constants, kinetic derivations, computational details, and additional analysis of MD trajectories (PDF)

\section{AUTHOR INFORMATION}

\section{Corresponding Authors}

Leif Hammarström - Department of Chemistry, Ångstrom Laboratory, Uppsala University, Uppsala 75120, Sweden; 구 orcid.org/0000-0002-9933-9084; Email: leif.hammarstrom@kemi.uu.se

Cecilia Tommos - Departments of Biochemistry and Biophysics, University of Pennsylvania, Philadelphia, Pennsylvania 191046059, United States; Department of Biochemistry and
Biophysics, Texas A\&M University, College Station, Texas 77843-2128, United States; Email: tommos@tamu.edu

\section{Authors}

Astrid Nilsen-Moe - Department of Chemistry, Angström Laboratory, Uppsala University, Uppsala 75120, Sweden

Clorice R. Reinhardt - Department of Molecular Biophysics and Biochemistry, Yale University, New Haven, Connecticut 06520, United States

Starla D. Glover - Department of Chemistry, Ångström Laboratory, Uppsala University, Uppsala 75120, Sweden

Li Liang - Departments of Biochemistry and Biophysics, University of Pennsylvania, Philadelphia, Pennsylvania 191046059, United States

Sharon Hammes-Schiffer - Department of Chemistry, Yale University, New Haven, Connecticut 06520, United States; (- orcid.org/0000-0002-3782-6995

Complete contact information is available at: https://pubs.acs.org/10.1021/jacs.0c04655

\section{Notes}

The authors declare no competing financial interest.

\section{ACKNOWLEDGMENTS}

C.R.R. is supported by the National Science Foundation Graduate Research Fellowship Program under Grant No. DGE1752134 and by the National Institutes of Health Grant 5T32GM06754 3-12. This work was also supported by National Institutes of Health Grants GM056207 (S.H.-S.) and GM79190 (C.T). Computational resources of the Yale Center for Research Computing (YCRC) were used for processing trajectories. Funding was also provided by the Swedish Research Council Grants 2016-04271 (L.H.) and 2017-04992 (S.D.G).

\section{REFERENCES}

(1) Selles Vidal, L.; Kelly, C. L.; Mordaka, P.ł M.; Heap, J. T. Review of $\mathrm{NAD}(\mathrm{P}) \mathrm{H}$-dependent oxidoreductases: Properties, engineering and application. Biochim. Biophys. Acta, Proteins Proteomics 2018, $1866,327-347$.

(2) Ferrer-Sueta, G.; Campolo, N.; Trujillo, M.; Bartesaghi, S.; Carballal, S.; Romero, N.; Alvarez, B.; Radi, R. Biochemistry of peroxynitrite and protein tyrosine nitration. Chem. Rev. 2018, 118, $1338-1408$.

(3) Page, C. C.; Moser, C. C.; Chen, X.; Dutton, P. L. Natural engineering principles of electron tunnelling in biological oxidationreduction. Nature 1999, 402, 47-52.

(4) Winkler, J. R.; Gray, H. B. Electron flow through metalloproteins. Chem. Rev. 2014, 114, 3369-3380.

(5) Hoffman, B. M.; Lukoyanov, D.; Yang, Z.-Y.; Dean, D. R.; Seefeldt, L. C. Mechanism of nitrogen fixation by nitrogenase: the next stage. Chem. Rev. 2014, 114, 4041-4062.

(6) Liu, J.; Chakraborty, S.; Hosseinzadeh, P.; Yu, Y.; Tian, S.; Petrik, I.; Bhagi, A.; Lu, Y. Metalloproteins containing cytochrome, iron-sulfur, or copper redox centers. Chem. Rev. 2014, 114, 43664469.

(7) Broderick, J. B.; Duffus, B. R.; Duschene, K. S.; Shepard, E. M. Radical S-adenosylmethionine enzymes. Chem. Rev. 2014, 114, 42294317.

(8) Migliore, A.; Polizzi, N. F.; Therien, M. J.; Beratan, D. N. Biochemistry and theory of proton-coupled electron transfer. Chem. Rev. 2014, 114, 3381-3465.

(9) Nordlund, P.; Sjöberg, B.-M.; Eklund, H. Three-dimensional structure of the free radical protein of ribonucleotide reductase. Nature 1990, 345, 593. 
(10) Tommos, C.; Babcock, G. T. Proton and hydrogen currents in photosynthetic water oxidation. Biochim. Biophys. Acta, Bioenerg. 2000, $1458,199-219$.

(11) Hammarström, L.; Styring, S. Proton-coupled electron transfer of tyrosines in Photosystem II and model systems for artificial photosynthesis: the role of a redox-active link between catalyst and photosensitizer. Energy Environ. Sci. 2011, 4, 2379-2388.

(12) Blomberg, M. R. Mechanism of oxygen reduction in cytochrome $\mathrm{c}$ oxidase and the role of the active site tyrosine. Biochemistry 2016, 55, 489-500.

(13) Wikström, M.; Krab, K.; Sharma, V. Oxygen activation and energy conservation by cytochrome c oxidase. Chem. Rev. 2018, 118, $2469-2490$

(14) Tarboush, N. A.; Jensen, L. M.; Yukl, E. T.; Geng, J.; Liu, A.; Wilmot, C. M.; Davidson, V. L. Mutagenesis of tryptophan199 suggests that hopping is required for MauG-dependent tryptophan tryptophylquinone biosynthesis. Proc. Natl. Acad. Sci. U. S. A. 2011, 108, 16956-16961.

(15) Liu, Z.; Tan, C.; Guo, X.; Li, J.; Wang, L.; Sancar, A.; Zhong, D. Determining complete electron flow in the cofactor photoreduction of oxidized photolyase. Proc. Natl. Acad. Sci. U. S. A. 2013, 110, 1296612971.

(16) Minnihan, E. C.; Nocera, D. G.; Stubbe, J. Reversible, longrange radical transfer in E. coli class Ia ribonucleotide reductase. Acc. Chem. Res. 2013, 46, 2524-2535.

(17) Gray, H. B.; Winkler, J. R. Hole hopping through tyrosine/ tryptophan chains protects proteins from oxidative damage. Proc. Natl. Acad. Sci. U. S. A. 2015, 112, 10920-10925.

(18) Gray, H. B.; Winkler, J. R. Living with oxygen. Acc. Chem. Res. 2018, 51, 1850-1857.

(19) Dixon, W. T.; Murphy, D. Determination of the acidity constants of some phenol radical cations by means of electron spin resonance. J. Chem. Soc., Faraday Trans. 2 1976, 72, 1221-1230.

(20) Mayer, J. M. Proton-coupled electron transfer: a reaction chemist's view. Annu. Rev. Phys. Chem. 2004, 55, 363-390.

(21) Reece, S. Y.; Nocera, D. G. Proton-coupled electron transfer in biology: results from synergistic studies in natural and model systems. Annu. Rev. Biochem. 2009, 78, 673-699.

(22) Hammes-Schiffer, S. Introduction: Proton-Coupled Electron Transfer. Chem. Rev. 2010, 110, 6937-6938.

(23) Weinberg, D. R.; Gagliardi, C. J.; Hull, J. F.; Murphy, C. F.; Kent, C. A.; Westlake, B. C.; Paul, A.; Ess, D. H.; McCafferty, D. G.; Meyer, T. J. Proton-coupled electron transfer. Chem. Rev. 2012, 112, 4016-4093.

(24) Rakowski DuBois, M.; DuBois, D. L. The roles of the first and second coordination spheres in the design of molecular catalysts for $\mathrm{H}$ 2 production and oxidation. Chem. Soc. Rev. 2009, 38, 62-72.

(25) Magnuson, A.; Anderlund, M.; Johansson, O.; Lindblad, P.; Lomoth, R.; Polivka, T.; Ott, S.; Stensjö, K.; Styring, S.; Sundström, V.; Hammarström, L. Biomimetic and microbial approaches to solar fuel generation. Acc. Chem. Res. 2009, 42, 1899-1909.

(26) Appel, A. M.; et al. Frontiers, opportunities, and challenges in biochemical and chemical catalysis of CO2 fixation. Chem. Rev. 2013, $113,6621-6658$.

(27) Rauchfuss, T. B. Diiron azadithiolates as models for the $[\mathrm{FeFe}]$ hydrogenase active site and paradigm for the role of the second coordination sphere. Acc. Chem. Res. 2015, 48, 2107-2116.

(28) Magnuson, A.; Berglund, H.; Korall, P.; Hammarström, L.; Åkermark, B.; Styring, S.; Sun, L. Mimicking electron transfer reactions in photosystem II: Synthesis and photochemical characterization of a ruthenium (II) tris (bipyridyl) complex with a covalently linked tyrosine. J. Am. Chem. Soc. 1997, 119, 10720-10725.

(29) Sjödin, M.; Styring, S.; Åkermark, B.; Sun, L.; Hammarström, L. Proton-Coupled Electron Transfer from Tyrosine in a TyrosineRuthenium- tris-Bipyridine Complex: Comparison with TyrosineZ Oxidation in Photosystem II. J. Am. Chem. Soc. 2000, 122, 39323936.

(30) Sjödin, M.; Styring, S.; Wolpher, H.; Xu, Y.; Sun, L.; Hammarström, L. Switching the redox mechanism: models for proton-coupled electron transfer from tyrosine and tryptophan. J. Am. Chem. Soc. 2005, 127, 3855-3863.

(31) Reece, S. Y.; Nocera, D. G. Direct tyrosine oxidation using the MLCT excited states of rhenium polypyridyl complexes. J. Am. Chem. Soc. 2005, 127, 9448-9458.

(32) Irebo, T.; Reece, S. Y.; Sjödin, M.; Nocera, D. G.; Hammarström, L. Proton-coupled electron transfer of tyrosine oxidation: Buffer dependence and parallel mechanisms. J. Am. Chem. Soc. 2007, 129, 15462-15464.

(33) Ishikita, H.; Soudackov, A. V.; Hammes-Schiffer, S. BufferAssisted Proton-Coupled Electron Transfer in a Model RheniumTyrosine Complex. J. Am. Chem. Soc. 2007, 129, 11146-11152.

(34) Fecenko, C. J.; Thorp, H. H.; Meyer, T. J. The Role of Free Energy Change in Coupled Electron- Proton Transfer. J. Am. Chem. Soc. 2007, 129, 15098-15099.

(35) Irebo, T.; Johansson, O.; Hammarström, L. The rate ladder of proton-coupled tyrosine oxidation in water: A systematic dependence on hydrogen bonds and protonation state. J. Am. Chem. Soc. 2008, 130, 9194-9195.

(36) Song, N.; Stanbury, D. M. Proton-coupled electron-transfer oxidation of phenols by hexachloroiridate (IV). Inorg. Chem. 2008, 47, $11458-11460$.

(37) Costentin, C.; Louault, C.; Robert, M.; Savéant, J.-M. The electrochemical approach to concerted proton-electron transfers in the oxidation of phenols in water. Proc. Natl. Acad. Sci. U. S. A. 2009, $106,18143-18148$.

(38) Bonin, J.; Costentin, C.; Louault, C.; Robert, M.; Routier, M.; Savéant, J.-M. Intrinsic reactivity and driving force dependence in concerted proton-electron transfers to water illustrated by phenol oxidation. Proc. Natl. Acad. Sci. U. S. A. 2010, 107, 3367-3372.

(39) Zhang, M.-T.; Hammarström, L. Proton-coupled electron transfer from tryptophan: A concerted mechanism with water as proton acceptor. J. Am. Chem. Soc. 2011, 133, 8806-8809.

(40) Bonin, J.; Costentin, C.; Louault, C.; Robert, M.; Savéant, J.-M. Water (in water) as an intrinsically efficient proton acceptor in concerted proton electron transfers. J. Am. Chem. Soc. 2011, 133, $6668-6674$

(41) Irebo, T.; Zhang, M.-T.; Markle, T. F.; Scott, A. M.; Hammarström, L. Spanning Four Mechanistic Regions of Intramolecular Proton-Coupled Electron Transfer in a $\mathrm{Ru}(\mathrm{bpy})_{3}{ }^{2+}-$ Tyrosine Complex. J. Am. Chem. Soc. 2012, 134, 16247-16254.

(42) Zhao, Y.; Swierk, J. R.; Megiatto, J. D.; Sherman, B.; Youngblood, W. J.; Qin, D.; Lentz, D. M.; Moore, A. L.; Moore, T. A.; Gust, D.; Mallouk, T. E. Improving the efficiency of water splitting in dye-sensitized solar cells by using a biomimetic electron transfer mediator. Proc. Natl. Acad. Sci. U. S. A. 2012, 109, 15612-15616.

(43) Dongare, P.; Maji, S.; Hammarström, L. Direct evidence of a tryptophan analogue radical formed in a concerted electron- proton transfer reaction in water. J. Am. Chem. Soc. 2016, 138, 2194-2199.

(44) Tommos, C.; Skalicky, J. J.; Pilloud, D. L.; Wand, A. J.; Dutton, P. L. De novo proteins as models of radical enzymes. Biochemistry 1999, 38, 9495-9507.

(45) Martínez-Rivera, M. C.; Berry, B. W.; Valentine, K. G.; Westerlund, K.; Hay, S.; Tommos, C. Electrochemical and structural properties of a protein system designed to generate tyrosine Pourbaix diagrams. J. Am. Chem. Soc. 2011, 133, 17786-17795.

(46) Glover, S. D.; Jorge, C.; Liang, L.; Valentine, K. G.; Hammarström, L.; Tommos, C. Photochemical tyrosine oxidation in the structurally well-defined $\alpha_{3} \mathrm{Y}$ protein: proton-coupled electron transfer and a long-lived tyrosine radical. J. Am. Chem. Soc. 2014, 136, 14039-14051.

(47) Dai, Q.-H.; Tommos, C.; Fuentes, E. J.; Blomberg, M. R.; Dutton, P. L.; Wand, A. J. Structure of a de novo designed protein model of radical enzymes. J. Am. Chem. Soc. 2002, 124, 10952-10953.

(48) Glover, S. D.; Tyburski, R.; Liang, L.; Tommos, C.; Hammarström, L. Pourbaix Diagram, Proton-Coupled Electron Transfer, and Decay Kinetics of a Protein Tryptophan Radical: Comparing the Redox Properties of $\mathrm{W}_{32}{ }^{\bullet}$ and $\mathrm{Y}_{32}{ }^{\bullet}$ Generated Inside 
the Structurally Characterized $\alpha_{3} \mathrm{~W}$ and $\alpha_{3} \mathrm{Y}$ Proteins. J. Am. Chem. Soc. 2018, 140, 185-192.

(49) Hay, S.; Westerlund, K.; Tommos, C. Moving a Phenol Hydroxyl Group from the Surface to the Interior of a Protein: Effects on the Phenol Potential and $\mathrm{p} K_{\mathrm{a}}$. Biochemistry 2005, 44, 1189111902.

(50) Tommos, C.; Valentine, K. G.; Martínez-Rivera, M. C.; Liang, L.; Moorman, V. R. Reversible phenol oxidation and reduction in the structurally well-defined 2-mercaptophenol- $\alpha_{3} \mathrm{C}$ protein. Biochemistry 2013, 52, 1409-1418.

(51) Ravichandran, K. R.; Liang, L.; Stubbe, J.; Tommos, C. Formal reduction potential of 3,5-difluorotyrosine in a structured protein: insight into multistep radical transfer. Biochemistry 2013, 52, 89078915.

(52) Ravichandran, K. R.; Zong, A. B.; Taguchi, A. T.; Nocera, D. G.; Stubbe, J.; Tommos, C. Formal reduction potentials of difluorotyrosine and trifluorotyrosine protein residues: Defining the thermodynamics of multistep radical transfer. J. Am. Chem. Soc. 2017, 139, 2994-3004.

(53) Lee, W.; Kasanmascheff, M.; Huynh, M.; Quartararo, A.; Costentin, C.; Bejenke, I.; Nocera, D. G.; Bennati, M.; Tommos, C.; Stubbe, J. Properties of site-specifically incorporated 3-aminotyrosine in proteins to study redox-active tyrosines: Escherichia coli ribonucleotide reductase as a paradigm. Biochemistry 2018, 57, 3402-3415.

(54) Berry, B. W.; Martínez-Rivera, M. C.; Tommos, C. Reversible voltammograms and a Pourbaix diagram for a protein tyrosine radical. Proc. Natl. Acad. Sci. U. S. A. 2012, 109, 9739-9743.

(55) Juris, A.; Balzani, V.; Barigelletti, F.; Campagna, S.; Belser, P. 1.; von Zelewsky, A. v. Ru (II) polypyridine complexes: photophysics, photochemistry, eletrochemistry, and chemiluminescence. Coord. Chem. Rev. 1988, 84, 85-277.

(56) Jorgensen, W. L.; Chandrasekhar, J.; Madura, J. D.; Impey, R. W.; Klein, M. L. Comparison of simple potential functions for simulating liquid water. J. Chem. Phys. 1983, 79, 926-935.

(57) Huang, J.; MacKerell, A. D., Jr CHARMM36 all-atom additive protein force field: Validation based on comparison to NMR data. J. Comput. Chem. 2013, 34, 2135-2145.

(58) Maier, J. A.; Martinez, C.; Kasavajhala, K.; Wickstrom, L.; Hauser, K. E.; Simmerling, C. ff14SB: improving the accuracy of protein side chain and backbone parameters from ff99SB. J. Chem. Theory Comput. 2015, 11, 3696-3713.

(59) Löw, C.; Weininger, U.; Lee, H.; Schweimer, K.; Neundorf, I.; Beck-Sickinger, A. G.; Pastor, R. W.; Balbach, J. Structure and dynamics of helix-0 of the N-BAR domain in lipid micelles and bilayers. Biophys. J. 2008, 95, 4315-4323.

(60) Patapati, K. K.; Glykos, N. M. Three force fields' views of the $3_{10}$ helix. Biophys. J. 2011, 101, 1766-1771.

(61) Best, R. B.; Mittal, J.; Feig, M.; MacKerell, A. D., Jr Inclusion of many-body effects in the additive CHARMM protein CMAP potential results in enhanced cooperativity of $\alpha$-helix and $\beta$-hairpin formation. Biophys. J. 2012, 103, 1045-1051.

(62) Chien, J.-Y. Kinetic analysis of irreversible consecutive reactions. J. Am. Chem. Soc. 1948, 70, 2256-2261.

(63) Endicott, J. F.; Caspari, G.; Hughes, R. G.; Hoffman, M. Z. Flash photolytic, isotope tracer, and chemical scavenging studies of the ultraviolet photochemistry of pentaamminecobalt (III) chloride. Evidence for excited-state intermediates. J. Am. Chem. Soc. 1970, 92, 6801-6810.

(64) Sjödin, M.; Irebo, T.; Utas, J. E.; Lind, J.; Merényi, G.; Åkermark, B.; Hammarström, L. Kinetic effects of hydrogen bonds on proton-coupled electron transfer from phenols. J. Am. Chem. Soc. 2006, 128, 13076-13083.

(65) Lubitz, W.; Reijerse, E. J.; Messinger, J. Solar water-splitting into $\mathrm{H}_{2}$ and $\mathrm{O}_{2}$ : design principles of photosystem II and hydrogenases. Energy Environ. Sci. 2008, 1, 15-31.

(66) Nick, T. U.; Ravichandran, K. R.; Stubbe, J.; Kasanmascheff, M.; Bennati, M. Spectroscopic evidence for a $\mathrm{H}$ bond network at
Y356 located at the subunit interface of active E. coli ribonucleotide reductase. Biochemistry 2017, 56, 3647-3656.

(67) Kang, G.; Taguchi, A. T.; Stubbe, J.; Drennan, C. L. Structure of a trapped radical transfer pathway within a ribonucleotide reductase holocomplex. Science 2020, 368, 424-427.

(68) Osborne, R. L.; Zhu, H.; Iavarone, A. T.; Blackburn, N. J.; Klinman, J. P. Interdomain long-range electron transfer becomes ratelimiting in the $\mathrm{Y} 216 \mathrm{~A}$ variant of tyramine $\beta$-monooxygenase. Biochemistry 2013, 52, 1179-1191. 